Brit. J. industr. Med., 1949, 6, 213.

\title{
WEIL'S DISEASE IN THE NORTH-EAST OF SCOTLAND
}

\author{
BY \\ J. SMITH \\ From the City Hospital Laboratory, Aberdeen \\ (RECEIVED FOR PUBLICATION JANUARY 7, 1949)
}

In 1939 Davidson and Smith reported on a series of 104 cases of Weil's disease which had occurred mainly amongst fish-workers in Aberdeen between the years 1934 to 1938 . Since that time a further series of cases has been investigated and the present paper now deals with Weil's disease between the years 1934 and 1948, during which period 214 cases have been encountered. In the interval a number of papers dealing with various aspects of this infection in this and other countries have been published. Thus, Stuart (1939) and Jenkins and Sharp (1946) have reported cases amongst miners ; Stewart and Witts (1944) and Gauld (1947) amongst bathers and military personnel; Broom and Alston (1948) have analysed a series of 195 cases which have been diagnosed in England, and in their list of occupations associated with the disease Army personnel take first place with 24 per cent., while farm, sewer, and fish workers account for 12, 11, and 7 per cent. respectively. Their overall fatality rate in one hundred cases in which they were able to obtain information was 19 per cent., while in 120 cases icterus was recorded in 107 , or 90 per cent. In America the position has been reviewed by Meyer and others (1939), Stiles and Sawyer (1942), and Bertucci (1945); and in Holland a complete review has been published by van Thiel (1948). Information on the incidence of infection amongst rats with $L$. icterohoemorrhagia has been the subject of a note by Allcroft (1945).

TABLE 1

PERSONS EMPLOYED IN FISH-CURING PREMISES DECEMBER, 1948

\begin{tabular}{c|c|c|c|c}
\hline $\begin{array}{c}\text { No. of } \\
\text { premises }\end{array}$ & $\begin{array}{c}\text { No. of } \\
\text { employees }\end{array}$ & Male & Female & Total \\
\hline 145 & Under 10 & 296 & 358 & 654 \\
62 & 11 to 25 & 367 & 535 & 902 \\
13 & 26 to 50 & 180 & 269 & 449 \\
8 & Over 50 & 235 & 314 & 549 \\
\hline 228 & - & 1,078 & 1,476 & 2,554 \\
\hline
\end{tabular}

\section{Epidemiology}

The fishing industry in Aberdeen is mainly concerned with the preparation for the retail market of white fish which has been brought into port by trawlers from the North Sea and from the vicinity of Iceland. The work is undertaken by a large number of firms who may employ from two to over fifty workers. The findings obtained as a result of a recent census undertaken under the direction of the Chief Sanitary Inspector are given in Table 1. Thus, in a total of 228 premises 2,554 persons were employed, 1,078 being males and 1,476 females. These figures do not include the men employed in the transport section of the industry, as their numbers have not been recorded. The majority of the workers employed as filleters and freshers are in the age-group 15 to 25 years. A few older men are more frequently employed in the packing and transport sections of the industry. As the young women grow up many are married, and this produces a constant change of personnel from year to year. The actual number of firms and the number of employees have not varied much in recent years. When a survey was made some years ago (Smith and Davidson, 1936) it was shown that fifty-one or $\mathbf{2 4 . 2}$ per cent., of blood samples from 210 individuals gave a positive agglutination test against $\boldsymbol{L}$. icterohamorrhagice in dilutions varying from 1 in 30 to 1 in 1,000. Further, in a control series from 406 individuals with no connexion with the fishing industry, not a single positive reaction was obtained. From these and other observations it was considered that Weil's disease occurred in three grades of severity: (1) severe infections associated with jaundice, (2) mild infections with pyrexia and no jaundice, (3) latent or inapparent infections with no clinical manifestations. It is obvious, therefore, that in the following description of the disease as it appears in Aberdeen only cases belonging to categories 1 and 2 are included, and the many latent or inapparent infections are not recognized. The actual risk of contracting infection 
TABLE 2

PLACE WHERE INFECTION WAS CONTRACTED

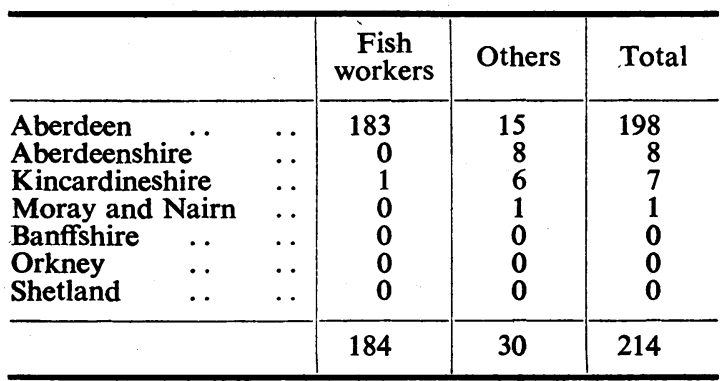

must have been very great at one time, but this risk has apparently been considerably lessened in recent years judging by the reduction of the number of cases occurring annually.

The distribution of cases in the north-east of Scotland is given in Table 2, from which it is seen that out of a total of 214 no less than 198 occurred in the City of Aberdeen, eight in Aberdeenshire, seven in Kincardineshire, and one in Morayshire. In the Counties of Banff, Orkney, and Shetland, no case has so far been diagnosed despite the fact that sera sent in from cases of pyrexia of unknown origin, and jaundice, have often been tested for leptospiral agglutinins. It should be noted also that the medical practitioners in the area have shown an increasing awareness of the possibility of the occurrence of Weil's disease, and, further, the patients, particularly fish workers, often call the attention of the practitioner to the fact that they

TABLE 3

OCCUPATIONAL INCIDENCE*

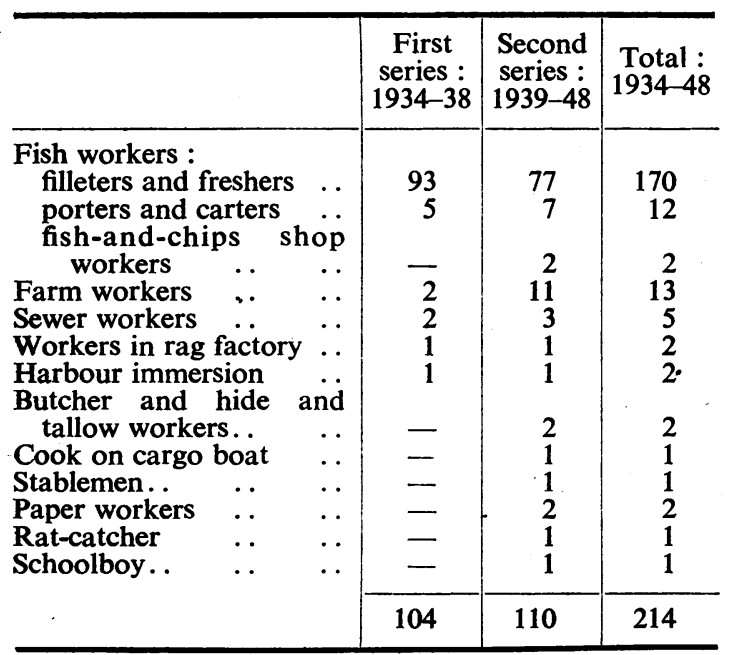

* Fish workers 86 per cent. of total. are possibly suffering from this disease. As regards the occupation of these patients, the details are given in Table 3, and the outstanding fact is that out of the total cases no less than 184 , or 86 per cent., occurred amongst fish workers. It should be noted that the term "fish workers" includes individuals employed as carters who assist in the transport of fish from the market to the curing yards, and from the curing yards to the retail shops and railway station. These men are presumably infected while handling the slimy wooden boxes which have been contaminated by the excretions of rats. Workers in fish-and-chips shops are also included in this category, since they presumably

TABLE 4

AGE AND SEX INCIDENCES OF CASES

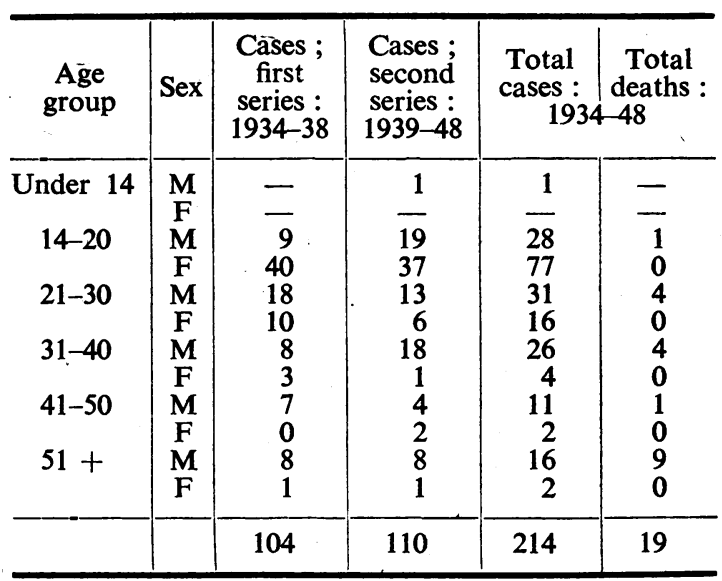

get infected from boxes and their contents which were previously infected at the wholesale merchants' premises or in the actual shop of the retailer.

Next in the list are farm workers with thirteen cases, and then sewer workers with five cases. It is obvious that by reason of the environmental conditions associated with their employment farm workers must be quite frequently exposed to the possibility of infection. The occurrence of five cases amongst sewer workers can be accounted for by the fact that large new construction projects have been under way in connexion with increased sewerage facilities. Two cases resulted from immersion in the harbour and one schoolboy admitted helping to clean ditches on the farm at home. The remaining eight cases had various occupations, and in each it is easy to envisage the conditions which would produce infection.

The age and sex distribution of the cases is given in Table 4, and the incidence as regards age and sex has been largely influenced by the preponderance of young people employed in the fishing industry. 
TABLE 5

ANALYSIS OF DEATHS

\begin{tabular}{|c|c|c|c|c|c|}
\hline & & & Cases & Deaths & $\%$ mortality \\
\hline $\begin{array}{l}\text { Total } \\
\text { Male } \\
\text { Female }\end{array}$ & $\begin{array}{l}\cdots \\
\cdots \\
\cdots\end{array}$ & $\begin{array}{l}\cdots \\
\cdots \\
\cdots\end{array}$ & $\begin{array}{l}214 \\
113 \\
101\end{array}$ & $\begin{array}{r}19 \\
19 \\
0\end{array}$ & $\begin{array}{c}8 \cdot 9 \\
16 \cdot 8 \\
0\end{array}$ \\
\hline $\begin{array}{c}\text { Under } 51 \\
\text { years }\end{array}$ & $\begin{array}{l}\text { male } \\
\text { female }\end{array}$ & $\begin{array}{l}\cdots \\
\cdots\end{array}$ & $\begin{array}{l}97 \\
99\end{array}$ & $\begin{array}{r}10 \\
0\end{array}$ & $\begin{array}{c}10 \cdot 3 \\
0\end{array}$ \\
\hline $\begin{array}{l}51 \text { years } \\
\text { or over }\end{array}$ & $\begin{array}{l}\text { male } \\
\text { female }\end{array}$ & $\begin{array}{l}\cdots \\
\cdots\end{array}$ & $\begin{array}{r}16 \\
2\end{array}$ & $\begin{array}{l}9 \\
0\end{array}$ & $\begin{array}{c}56 \cdot 2 \\
0\end{array}$ \\
\hline
\end{tabular}

Thus in the age group 14 to 20 years, out of 105 cases seventy-seven were females, while in the older age groups in which many of the female workers have given up their employment, the males are then in the majority and they carry out duties which would not at any rate be suitable for women. The youngest case in this series was a schoolboy aged 8 years, and it seems altogether very unusual to find so young a person infected. In all there were a total of 113 male to 101 female cases.

The case mortality rates are given in Table 5 . Here the outstanding features are a low overall rate of 8.9 per cent. with a rate for males of 16.8 per cent. and none for females. Under 50 years of age the male mortality rate is 10.3 per cent., while over this age the mortality was nine deaths in sixteen cases, or 56.2 per cent. It seems noteworthy that despite there being 101 female cases there was not a single death, but it should be remembered that seventy-seven of these were under the age of 21 years. On the other hand had the mortality rate been similar for both sexes seven to eight deaths should have occurred in the female group.

Though the annual and monthly figures for all cases are comparatively small, Table 6 shows that up to 1941 the number of cases varied annually from seventeen to a maximum of twenty-six in 1938, while since 1941 the number has varied from four in 1944 to eleven in 1948. Taking the total monthly incidence the lowest figures were obtained in February and March, and the highest in September, there being a gradual rise and decline in the months preceding and following. It is difficult to be certain why there should be a maximum incidence in the early autumn, but it may have some relationship to the suitability of atmospheric temperatures for survival of the leptospira or it may be connected with biological changes in the rat population.

One factor which may account for the occurrence of Weil's disease in Aberdeen and its non-occurrence in other towns with a similar type of fishing industry (Hampson, 1946), is that the water supply in Aberdeen has an almost neutral $p \mathrm{H}$, whereas in other towns the water may not have such a reaction.

TABLE 6

MONTHLY AND YEARLY DISTRIBUTION OF ALL CASES

\begin{tabular}{|c|c|c|c|c|c|c|c|c|c|c|c|c|c|c|c|c|c|}
\hline & $19:$ & 34 & 35 & 36 & 37 & 38 & 39 & 40 & 41 & 42 & 43 & 44 & 45 & 46 & 47 & 48 & Total \\
\hline January & .. & 0 & 4 & 4 & 0 & 2 & 2 & 0 & 1 & 0 & 1 & 0 & 0 & 1 & 0 & 0 & 15 \\
\hline February & . & 0 & 0 & 0 & 0 & 2 & 2 & 1 & 1 & 0 & 0 & 0 & 0 & 0 & 1 & 1 & 8 \\
\hline March.. & .. & 0 & 0 & 2 & 0 & 0 & 1 & 1 & 1 & 1 & 0 & 0 & 0 & 1 & 0 & 1 & 8 \\
\hline April .. & .. & 1 & 0 & 0 & 4 & 2 & 1 & 1 & 0 & 1 & 0 & 0 & 0 & 0 & 1 & 1 & 12 \\
\hline May .. & .. & 2 & 3 & 0 & 2 & 1 & 2 & 1 & 1 & 1 & 4 & 0 & 0 & 0 & 1 & 1 & 19 \\
\hline June $\quad$. & . & 4 & 0 & 1 & 1 & 2 & 1 & 1 & 0 & 0 & 0 & 0 & 1 & 1 & 0 & 2 & 14 \\
\hline July $\quad$. & .. & 1 & 2 & 0 & 2 & 1 & 2 & 4 & 4 & 1 & 1 & 0 & 1 & 1 & 1 & 1 & 22 \\
\hline August & .. & 0 & 0 & 1 & 2 & 6 & 3 & 4 & 5 & 1 & 0 & 0 & 0 & 1 & 1 & 1 & 25 \\
\hline September & . & 2 & 4 & 5 & 2 & 3 & 6 & 0 & 3 & 3 & 0 & 3 & 1 & 1 & 1 & 3 & 37 \\
\hline October & .. & 4 & 2 & 4 & 4 & 1 & 0 & 1 & 2 & 1 & 0 & 0 & 3 & 1 & 0 & 0 & 23 \\
\hline November & .. & 5 & 2 & 0 & 2 & 1 & 2 & 3 & 0 & 1 & 0 & 0 & 0 & 0 & 0 & 0 & 16 \\
\hline \multirow[t]{2}{*}{ December } & . & 5 & 0 & 0 & 1 & 5 & 1 & 0 & 2 & 0 & 0 & 1 & 0 & 0 & 0 & 0 & 15 \\
\hline & & 24 & 17 & 17 & 20 & 26 & 23 & 17 & 20 & 10 & 6 & 4 & 6 & 7 & 6 & 11 & 214 \\
\hline
\end{tabular}


It has been shown by Chang and others (1948) that leptospira may survive for four weeks in neutral tap water which has, in addition, a small amount of food supply. Further, since 1941 there has been a considerable decrease in the annual number of recognized cases of the disease and it is difficult to say why this should be so. In October 1940 a start was made to chlorinate the City water supply but during the last quarter of 1940 and the first half of 1941 chlorination was maintained for only about twelve hours per day. After June 20, 1941, chlorination became a more continuous process but the proper equipment for controlling this did not become available until the late autumn. It used to be the practice in the laboratory to prepare Vervoot's leptospiral medium with tap water, but after the introduction of chlorination the leptospira would not grow on media so prepared. As has already been shown by Smith and Davidson (1936), the presence of a chlorine derivative in water acts most successfully against leptospira. Chang and others (1948) have also shown that when residual chlorine was present to the extent of 1 part per million (p.p.m.) this organism only survived three minutes. At the present time only 0.5 p.p.m. are added to the municipal water supply after filtration, and by the time the water arrives at the tap no trace can be obtained of residual chlorine by the usual tests, although the water is practically sterile. It may be possible, therefore, that the chlorine combined with the organic matter present in the water is still to some extent inimical to the leptospira with which it comes in contact in the fish curing premises.

The incidence of the cases amongst fish workers as they occurred in certain curing yards is of some interest. Some curing yards have contributed quite a number of cases, the highest being seventeen, followed by fifteen in another and ten in a third. Obviously those premises in which these cases continue to occur require a thorough overhaul from the point of view of controlling rat infestation. As the fish curing yards are located in the vicinity of the harbour, and as there are frequently a number of business premises in each street, and as the premises in five streets have produced from eleven to twenty-three cases, this again is an obvious indication of the necessity to prosecute a vigorous campaign of rat destruction.

\section{Clinical Manifestations}

General.- These will be only briefly dealt with as they apply to the situation in Aberdeen and the north-east of Scotland. The course of the disease may be divided into three stages. The first or febrile stage lasts approximately one week, and during the first few days septicæmia seems to be the invariable rule, and only towards the end of the week do antibodies begin to appear in the serum. The initial symptoms of sudden onset, chill, fever, headache, and muscular pains, seem to be almost inevitable in every case. Prostration and vomiting are frequently present, and within a day or two conjunctivitis is evident in most. In fact the occupational history associated with the symptoms already described are almost indicative of Weil's disease as seen in Aberdeen. Jaundice appeared in 65 per cent. of the first series and 63 per cent. of the second series, or an average of 64 per cent. of all cases. Toxic nephritis, with albumin in the urine, is almost always present at some time during the first and later stages, and is often accompanied by the presence of red blood cells and casts.

The second or toxic stage is characterized by the absence of leptospira in the blood and the development of antibodies in the serum. In moderately severe cases the fever abates and the clinical condition improves ; but the jaundice continues and the toxic nephritis may be present for a month. In cases doing badly the jaundice becomes more marked, but this in itself need not cause alarm unless accompanied by severe hæmorrhage into the skin, mucous membranes, and various organs. The bad prognostic symptoms are reduced excretion of urine and a rapidly rising blood urea, death invariably being due to kidney failure which is accompanied by a falling blood pressure and a rapidly increasing pulse. The third or convalescent stage is characterized by the rapidly increasing titre of antibodies in the blood, the presence of leptospira in the urine, and the occurrence of secondary fever which is present in about half the cases.

In the previous series of 104 cases, six deaths were reported, but in the present additional 110 cases, thirteen have occurred, making nineteen in all. The particulars of the fatal cases are given in Table 7, from which it is seen that the shortest period of survival after the onset was recorded as five, and the longest twenty days, and since both these patients died at home the information on these points was obtained from the family doctor. The youngest fatal case was a man aged 18 , and the oldest a man aged 72 years. The figures for icteric index and blood urea are dependent on the time after the onset at which the blood samples have been collected, but all fatal cases were clinically icteric.

\section{Special Examinations}

Blood Examination.-Blood examinations have been carried out on many cases and often there 
has been little change from normal. Certain cases do show a definite polymorphonuclear leucocytosis of 10,000 to 30,000 leucocytes per c.mm. of blood, but the rise cannot be associated with any particular clinical symptom. In those cases showing severe toxæmia and purpura the loss of blood may even reduce the erythrocyte count to $1,500,000$ and the hæmoglobin to 25 per cent.

Biochemical Examination.-The most important blood constituent from the point of view of prognosis is the urea. This was found to be over $40 \mathrm{mg}$. per $100 \mathrm{ml}$. of blood in 60 per cent. of cases in the first series, and 59 per cent. in the second series. As death is almost always due to uræmia, high values of 400 to $500 \mathrm{mg}$. per $100 \mathrm{ml}$. were encountered before a fatal termination. The icteric index was very variable in those cases showing jaundice but was frequently between 50 and 100 . One case showed an icteric index of 200 but the severity of the jaundice is not such a bad prognostic sign as the severity of the toxic nephritis.

Meningitis.-Frequent mention of meningitis associated with a leptospiral infection occurs in the literature, and in the review by Walch-Sordrager (1939) an analysis of the incidence of this manifestation as it occurs in Holland is given. Of a total of 327 cases 12 per cent. showed evidence of meningitis, but in the present series there was a higher incidence amongst the non-jaundiced group, (23 per cent.) than amongst the jaundiced group, of whom only 5 per cent. were so affected. Many cases were lumbar punctured when the patient

TABLE 7

PARTICULARS OF FATAL CASES : ALl MALES

\begin{tabular}{|c|c|c|c|c|c|c|c|}
\hline \multirow{3}{*}{$\begin{array}{l}\text { Case } \\
\text { No. }\end{array}$} & \multirow{3}{*}{ Age } & \multirow{3}{*}{$\begin{array}{l}\text { Days ill on } \\
\text { admission }\end{array}$} & \multicolumn{5}{|c|}{ Blood } \\
\hline & & & \multicolumn{2}{|c|}{ Bacteriological findings } & \multicolumn{3}{|c|}{ Biochemical } \\
\hline & & & $\begin{array}{c}\text { Leptospira } \\
\text { present }\end{array}$ & $\begin{array}{c}\text { Serum } \\
\text { agglutinins }\end{array}$ & $\begin{array}{l}\text { Icteric } \\
\text { index }\end{array}$ & $\begin{array}{l}\text { Blood } \\
\text { urea }\end{array}$ & $\begin{array}{l}\text { Day of } \\
\text { death }\end{array}$ \\
\hline 12 & 63 & 8 & - & $1 / 1000$ & - & - & 9 \\
\hline 39 & 45 & 8 & - & $1 / 300$ & 60 & 397 & 9 \\
\hline 43 & 61 & 6 & - & $1 / 30$ & 89 & 250 & 8 \\
\hline 79 & 68 & Home & - & $1 / 1000$ & 63 & 89 & 8 \\
\hline 81 & 59 & 7 & + & $1 / 10$ & 67 & 161 & 10 \\
\hline 99. & 27 & 4 & + & - & 150 & 300 & 10 \\
\hline 128 & 26 & 5 & + & $1 / 500$ & - & 一 & 10 \\
\hline 132 & 28 & 6 & - & $1 / 30$ & - & - & 8 \\
\hline 145 & 72 & 6 & - & $1 / 300$ & - & - & 10 \\
\hline 150 & 62 & 7 & - & $1 / 10$ & 88 & 460 & 14 \\
\hline 156 & 18 & 5 & + & $1 / 300$ & 78 & $152+$ & 11 \\
\hline 177 & 40 & 4 & + & - & 180 & 320 & 9 \\
\hline 187 & 54 & 4 & + & $1 / 1000$ & 32 & 257 & 14 \\
\hline 191 & 60 & Home & + & - & - & - & 5 \\
\hline 194 & 62 & Home & - & $1 / 300$ & - & - & 20 \\
\hline 195 & 35 & 5 & + & $1 / 30$ & 60 & 241 & 9 \\
\hline 204 & 39 & 6 & + & $1 / 1000$ & . 90 & 220 & 9 \\
\hline 205 & 33 & 4 & + & $1 / 30$ & 100 & 315 & 8 \\
\hline 208 & 25 & 5 & + & $1 / 300$ & 58 & 526 & 11 \\
\hline
\end{tabular}


complained of headache and slight neck stiffness but usually the protein and cell count of the cerebrospinal fluid was normal. Thus only 17 cases or 8 per cent. showed evidence of meningitis as judged by changes in the cerebrospinal fluid, and the details are given in Table 8 . The protein content was usually from 50 to $80 \mathrm{mg}$. per $100 \mathrm{ml}$. with a maximum in one case of $120 \mathrm{mg}$. per $100 \mathrm{ml}$. The cell counts ranged from 6 to 600 per c.mm. of blood, and the relative proportion of polymorphs to lymphocytes also varied greatly. Repeated attempts by culture and guinea-pig inoculation have always failed to demonstrate leptospira in the cerebrospinal fluid.

\section{Bacteriological Diagnosis}

In the diagnosis of Weil's disease a proper application of bacteriological and serological tests is essential, and this again is dependent upon the correct understanding of the course of the infection. The disease is, during a short period, essentially a septicæmia, and the subsequent manifestations such as hæmorrhage, jaundice, and nephritis are a consequence of the toxæmia. The diagnosis at the septicæmic stage can only be made by culture of the blood in a suitable type of leptospiral culture media, or by inoculation of the specimen intraperitoneally into young guinea-pigs. Unfortunately the results of either procedure cannot become available for some days. The period required for leptospira to be demonstrable in a blood culture is variable and is at least a week, while inoculation of the blood clot into a guinea pig will produce a fatal result in seven to nine days if leptospira are present.

The recovery of the leptospira in this investigation has been, almost invariably, by guinea-pig inoculation, two animals being inoculated intraperitoneally

TABLE 8

CASES WITH MENINGITIS

FINDINGS IN CEREBROSPINAL FLUIDS

\begin{tabular}{|c|c|c|c|c|c|c|}
\hline \multirow{2}{*}{ Case No. } & \multirow{2}{*}{$\begin{array}{l}\text { Day of } \\
\text { illness }\end{array}$} & \multirow{2}{*}{ Protein } & \multicolumn{4}{|c|}{ Cells } \\
\hline & & & Total & Polymorphs & Lymphocytes & Chlorides \\
\hline \multirow{2}{*}{30} & $\int 6$ & 60 & 238 & 67 & 33 & 706 \\
\hline & 8 & 40 & 180 & 17 & 83 & 711 \\
\hline 55 & 7 & 35 & 240 & 51 & 49 & - \\
\hline 58 & 6 & 25 & 105 & 2 & 98 & 714 \\
\hline 66 & 6 & 60 & 242 & 3 & 97 & - \\
\hline 68 & 6 & 80 & 42 & 9 & 91 & 一 \\
\hline 70 & 8 & 50 & 111 & 12 & 88 & - \\
\hline \multirow{2}{*}{74} & 3 & 30 & 0 & - & 一 & - \\
\hline & 5 & 50 & 30 & 58 & 42 & - \\
\hline 75 & 7 & 65 & 243 & 32 & 68 & 一 \\
\hline 91 & 9 & 65 & 84 & 26 & 74 & - \\
\hline 102 & 11 & 70 & 20 & 3 & 97 & - \\
\hline 106 & 6 & 120 & 78 & 36 & 64 & 710 \\
\hline 113 & 8 & 35 & 93 & 9 & 91 & 708 \\
\hline 128 & 9 & 45 & 37 & 17 & 83 & 714 \\
\hline 168 & 7 & 70 & 6 & 0 & 6 & 696 \\
\hline 182 & 9 & 50 & 75 & 32 & 68 & 730 \\
\hline 186 & 6 & 80 & 600 & 20 & 80 & 710 \\
\hline 194 & 4 & 80 & 370 & 69 & 31 & 724 \\
\hline
\end{tabular}


TABLE 9

BLOOD : BACTERIOLOGICAL FINDINGS IN 187 CASES

Presence of leptospira as shown by guinea-pig inoculation

\begin{tabular}{|c|c|c|c|c|c|c|c|c|c|c|}
\hline Day of disease & 1 & 2 & 3 & 4 & 5 & 6 & 7 & 8 & 9 & 10 \\
\hline No. + ve .. & 4 & 10 & 14 & 24 & 24 & 13 & 3 & 1 & 0 & $\mathbf{0}$ \\
\hline No. - ve .. & 0 & 0 & 0 & 0 & 20 & 36 & 21 & 15 & 1 & 1 \\
\hline$\%$ +ve $\ldots$ & 100 & 100 & 100 & 100 & 55 & 27 & 12 & 6 & 0 & 0 \\
\hline
\end{tabular}

through a large-bore needle with broken up clotted blood. This procedure is dispensed with when the patient has been ill for a period of seven or more days, and when the result of the serological test indicates a fairly high titre of antibodies. Table 9 summarizes the attempts at recovery of the organism. During the first four days after onset recovery of the leptospira is the rule, while on the fifth day only 55 per cent. of specimens showed the presence of the organism, and the percentage of positive results thereafter decreased still further. The results in Table 9 should be compared with summary of the serological tests in Table 10 . The earliest day after the onset at which agglutinins have been encountered is the fourth, the number positive and the titre of the serum rapidly increasing in the succeeding days until by the ninth or tenth day with few exceptions a positive serological result is to be found. Two cases have been encountered in which, as noted by Broom (1948), the agglutinins did not appear until after the tenth day. This, however, is a very exceptional occurrence. Occasional difficulty in obtaining bacteriological proof also arises when a patient is admitted with a severe form of the disease about the sixth day after the onset and dies within a day or two ; by that time the leptospira may have disappeared from the blood and the antibodies may be absent or present only in low dilutions of the serum. Investigation of the urinary excretion of leptospira has not been carried out as a routine, as the results obtained are so variable and as the excretion occurs most frequently at a time when diagnosis has already been established by other means.

\section{Treatment}

Since the introduction of penicillin this antibiotic has been used in place of the specific antiserum in the treatment of cases of Weil's disease admitted to this hospital. There can be no doubt about the bactericidal and bacteriostatic action of penicillin on leptospira. The experimental work of Alston and Broom (1944), Heilman and Herrell (1944), and Larson and Griffiths (1945) on guinea-pig and hamster infections, has clearly shown the curative action of the drug when it is administered in the early stages of the infection. Clinical reports on treatment of human cases by Bulmer (1945) and Cross (1945) are now available, but the number of cases treated so far does not permit a proper evaluation of this form of therapy. It would seem, however, that penicillin must be administered within the first four days, when the septicæmic stage is present ; otherwise the action of the drug can avail the patient little when a toxic nephritis has developed. Since penicillin became available sixteen cases febrile on admission have so far been treated with doses ranging from 200,000 to $2,000,000$ units daily, and four of these died. Sometimes it was thought that the penicillin had been responsible for the elimination of fever, but the patients were usually admitted at the time when defervescence would

TABLE 10

SEROLOGICAL TESTS ON SERUM

\begin{tabular}{ll|r|r|r|r|r|r|r|r|r|r}
\hline & \multicolumn{10}{c}{ Day of disease } \\
\cline { 2 - 8 } & & 1 & 2 & 3 & 4 & 5 & 6 & 7 & 8 & 9 & $\begin{array}{c}10 \text { and } \\
\text { over }\end{array}$ \\
\hline No. negative 1/10 dilution &.. & 2 & -7 & 9 & 17 & 24 & 20 & 7 & 2 & 0 & 2 \\
No. positive 1/10 dilution &.. & 0 & 0 & 0 & 1 & 15 & 31 & 31 & 36 & 23 & 99 \\
\% positive 1/10 or greater ... & 0 & 0 & 0 & 6 & 38 & 61 & 82 & 95 & 100 & 98 \\
\hline
\end{tabular}


have occurred normally. So far as the highly toxic cases were concerned it did not seem to mitigate the course of the infection in any way. This series of cases is, however, too small to permit any general deduction to be made.

\section{Workmen's Compensation}

Weil's disease in the majority of instances occurs as an occupational hazard, and in Great Britain a legal precedent was established in the Court of Session, when an award was confirmed in the case of Raeburn v. Lochgelly Iron and Coal Company Ltd. (20 B.W.C.C. 637). Further, the Report of the Departmental Committee on Compensation for Industrial Disease, which was issued in 1936, recommended that infection by $L$. icterohamorrhagice should entitle a workman to compensation for disablement, and that it should be scheduled as an industrial disease under Section 43 of the Workmen's Compensation Act, 1925. Actually there has been very little in the way of dispute about compensation. Men and women affected with the disease have, until the introduction of the National Insurance Act, received compensation automatically after a certificate had shown that they were undoubtedly suffering from a leptospiral infection. In some of the cases which ended fatally certain of the insurance companies have from time to time been inclined to dispute the fact that the disease was contracted by the individual while at work, but after an explanation was given of how the infection was contracted all cases have been settled out of court. With the introduction of the National Insurance Act the State has now taken over the responsibility for financial compensation from employers and insurance companies.

\section{Summary}

1. A survey has been made of 214 cases of Weil's disease which have occurred in the North-eastern area of Scotland between 1934 and 1948.

2. No fewer than 184 cases, or 86 per cent., occurred amongst fish workers.

3. The overall case mortality rate was 8.9 per cent., with a mortality rate for males of 16.8 per cent. and none for females.

4. Since penicillin became available sixteen cases febrile on admission have been treated with this antibiotic. It is believed, however, that antisera and antibiotics can influence the course of the disease only if given in the early stage of the septicæmia. It is not believed that their administration can influence the toxic nephritis which seems to be invariably fatal.

\section{REFERENCES}

Allcroft, R. (1945). Bull. Hyg.; 20, 371.

Alston, J. M., and Broom, J. C. (1944). Brit. med. J., 2, 718.

Bertucci, E. A. (1945). Amer. J. med. Sci., 209, 86.

Broom, J. C. (1948). J. clin. Path., 1, 232.

Broom, J. C. (1948). J. (1948). Lancet, 2, 96.

Bulmer, E. (1945). Brit. med. J.; 1, 113 .

Chang, S. L., Buckingham, M., and Taylor, M. P. (1948). J. infect. Dis., 82, 256.

Cross, R. M. (1945). Lancet, 1, 211.

Davidson, L. S. P., and Smith, J. (1936). Quart. J. Med., n.s., 5, 263.

Gaud Smith, J. (1939). Brit. med. J., 2, 753.

Gauld, W. R. (1947). Lancet, 1, 216.

Hampson, F. (1946). Bull. Min. Hith. and Publ. Hlth. Lab. Service, 5,155 .

Heilman, F. R., and Herrell, W. E. (1944). Proc. Mayo Clin., 19, 89. Jenkins, T. H., and Sharp, W. C. (1946). Brit. med. J. 1, 714.

Larson, C. L., and Griffits, J. S. (1945). Publ. Hith. Rep., Wash., 60,317 .

Meyer, K. F., Stewart-Anderson, B., and Eddie, B. (1939). Amer. J. Publ. Hlth., 29, 347

Smith, J., and Davidson, L. S. P. (1936). J. Hyg., Camb., 36, 438

Smith, J., and Davidson, L. S. P. (1936). J. Hyg., Camb.,

Stiles, W. W., and Sawyer, W. A. (1942). J. Amer.med. Ass., 118, 34

Stuart, R. D. (1939). J. Hyg., Camb., 39, 316.

Walch-Sordrager, B. (1939). Bull. of Hith. Org. Leag. of Nations, $8,142$.

Van Thiel, P. A. (1948). “ Leptospirosis.” Univ. Pers., Leiden. 